\title{
Governance with Poor Investor Protection: Evidence from Top Executive Turnover in Italy
}

\author{
Paolo F. Volpin* \\ London Business School
}

March 2001

\begin{abstract}
This paper analyzes executive turnover and firm valuation in Italy, a country that features all the characteristics of the most common governance structure around the world, as described by La Porta, et al. (1999): low legal protection for investors, firms with large controlling shareholders and pyramidal groups. The main findings are that turnover is significantly lower and unaffected by performance when the controlling shareholder of the firm is also a top executive in the firm, while it is more sensitive to performance when control is, to some extent, contestable and when the controlling shareholder owns a larger fraction of the firm's cash-flow rights. The results on valuation are the mirror image of those on turnover: the firm's $Q$ is lower for companies with the controlling shareholder as a top executive, larger when a voting syndicate controls the firm, and increases with the fraction of cash-flow rights owned by the controlling shareholder.
\end{abstract}

JEL classification: G34, J63, L14.

Keywords: Management turnover, corporate governance, pyramidal groups.

* The author is Chase Manhattan Research Fellow at London Business School.

Author's address: Institute of Finance and Accounting, London Business School, Regent's Park, London NW1 4SA, United Kingdom. E-mail: pvolpin@london.edu.

Acknowledgements: I thank Julian Franks, Rafael La Porta, Marco Pagano, Andrei Shleifer, and participants at seminars at the London School of Economics and Harvard University for helpful comments. I also thank Richard Frost and Samanta Padalino for useful suggestions. I acknowledge support from the National Science Foundation Graduate Fellowship program. 


\section{Introduction}

The separation between ownership and control, which characterizes capitalist economies, is limited by the extent to which laws and institutions guarantee sufficient return to investors from their investment. Legal protection and concentrated ownership are the main tools available to investors to protect their interests against the risk of expropriation by management. According to Shleifer and Vishny (1997), any developed economy uses a combination of these two instruments to solve the agency problem intrinsic in a financing relationship. Even if both are necessary, they are, to some extent, substitutes: whenever one of the two is lacking, there is more need for the other one (La Porta, et al., 1999).

Italy features most of the characteristics of the "typical" corporate governance structure around the world, as identified by La Porta, et al. (1999): weak legal protection for both creditors and shareholders, relatively inefficient law enforcement, high ownership concentration and some separation of ownership from control obtained via pyramidal groups and, to a smaller extent, nonvoting shares. Italy is therefore an ideal setting to study the effectiveness of such a common governance structure.

On the one hand, we expect high ownership concentration to help solve the managerial agency problem because controlling shareholders have the incentives and the power to discipline management. On the other hand, the existence of powerful controlling shareholders creates the conditions for a new agency problem because the interests of controlling and minority shareholders may not be perfectly aligned. There are different ways in which controlling shareholders can expropriate minority ones and gain private benefits of control. Some examples are targeted issues and repurchases of securities, transfers of assets, entrenchment, exploitation of a business relationship with controlled companies through transfer pricing, and, in general, the pursuance of personal objectives instead of the maximization of shareholder value. ${ }^{1}$ The large voting premium (82 percent) found by Zingales (1994) in companies with dual-class shares is suggestive evidence that the size of the private benefits of control is particularly large in Italy. Some theoretical papers suggest that the balance between the two forces is likely to be in favor of the second one, leading to a

\footnotetext{
${ }^{1}$ Johnson, et al. (2000) call this form of agency problem tunneling and describe some cases.
} 
magnification rather than a reduction of the agency problems. ${ }^{2}$ However, there is no direct evidence of this inefficiency. This paper tries to provide such evidence.

According to Kaplan (1994) and Coffee (1999), testing whether executive turnover increases as a firm's performance declines is one way to assess the effectiveness of a corporate governance system. An alternative way, suggested by Morck, et al. (1988) and McConnell and Servaes (1990), is to analyze the firm's valuation in relation with similar companies.

Hence, first, this paper will study the determinants of executive turnover in Italian traded companies, by focusing, in particular, on how the ownership and control structure of a firm affects the sensitivity of the firm's executive turnover to performance. Then, it will evaluate the effect of these same factors on the firm's Q. Both analyses are based on an extensive dataset, which covers all traded companies in Italy (banks and insurance companies excluded) for the period 1986-1997 and contains information on ownership, board and capital structures. For all companies in the sample, I was able to trace back the control chain, identify the ultimate owner and determine his ownership stake in the company, distinguishing between voting and cash flow rights. ${ }^{3}$

The first finding in the analysis is that turnover is significantly lower (and unaffected by performance) when the controlling shareholders are among the top executives. This result is evidence that the controlling shareholders are entrenched. I also find that the larger the fraction of cash flow rights owned by the controlling shareholder, the more sensitive turnover is to performance. This second result suggests that incentives matter and that governance improves when the controlling shareholder internalizes to a fuller extent the consequences of his actions. This incentive effect is however weaker than the entrenchment one, since I find that controlling shareholders are entrenched even in companies where they own a large fraction of cash flow rights. The third result of the analysis is that turnover is more sensitive to performance when a voting syndicate controls the firm. A voting syndicate is a coalition of relevant shareholders who sign a binding agreement to vote together for a few years. About 15 percent of the companies in the sample have a voting syndicate. These coalitions typically help the largest shareholder to control a company when his stake would not be large enough to do so by himself. This result suggests that turnover becomes more sensitive to performance when control is, to some extent, contestable, as in the case of a voting syndicate.

\footnotetext{
${ }^{2}$ In particular, I refer to Bebchuk (1999), Wolfenzon (1998) and Bebchuk, Kraakman and Triantis (1998).

${ }^{3}$ An example is provided in Figure 1.
} 
Moreover, in these cases, I find that even the controlling shareholder (that is, the largest shareholder in the voting syndicate) is more likely to be replaced after a bad performance.

These findings are confirmed in the analysis of the firm's Q: Q increases with the fraction of cashflow rights owned by the controlling shareholder, is significantly smaller firms in which the controlling shareholders are among the top executives, and is significantly larger when control is partially contestable as in the cases in which a voting syndicate controls the firm. ${ }^{4}$

The combination of the results on executive turnover and Q strongly suggests that governance forces are weak in Italian firms. This confirms the expectation that the most common governance structure around the world entails considerable agency costs.

The paper contains several other results. Within pyramidal groups, I find that turnover is independent of performance both at the top (in the holding companies) and at the bottom (in the subsidiaries of level 3 and higher) of a pyramid. In the holding companies turnover is very low (less than 6 percent), while in the subsidiaries turnover is relatively high (16 percent). The result for the companies at the top of a pyramid is largely due to the fact that the controlling shareholders of the group sit as executives of their holding companies and they are entrenched in control. I argue that they do so because the benefits of control are larger in the holding company, as suggested by the finding that the voting premium in the holding companies is significantly higher than in the subsidiaries. Regarding the executive turnover at the bottom of the pyramid, a possible explanation is that good managers are promoted to a higher layer of the pyramidal goup. In order to control for that possibility, I have redefined turnover as a situation in which the executive leaves the group, rather than just the firm. In this case, I find that turnover is much lower, but is still unaffected by the firm's performance at the bottom of pyramidal groups. This suggests that the managerial market within the group is operating, but that it cannot fully explain the lack of sensitivity of turnover to performance.

I also look at the channels through which performance affects turnover. When I consider the market of corporate control, I find that turnover increases substantially after a transfer of the controlling stake, and that transfers of control are more likely if the firm's past performance is worse. However, conditional on a transfer of control, turnover is independent of past performance. These results are weaker than, but partially consistent with, the findings of Martin and McConnell (1991) for the US and Franks and Mayer (1996) for the UK. When I consider firms that default or, in 
general, cases in which control shifts to the firm's creditors, I find that turnover increases substantially after a transfer of control to creditors and also, conditional on a transfer of control, that it is more likely if past performance was worse. These results are similar to Gilson (1989) for the US and Franks, et al. (2000) for the UK.

The structure of the paper is as follows: section 2 formulates the hypothesis to test by overviewing the literature and describing the Italian corporate governance system; section 3 describes the data set; section 4 contains and discusses the results on the determinants of top executive turnover and firm valuation. The conclusion is in section 5 .

\section{Existing literature and testable hypotheses}

Studying top executive turnover and the sensitivity of turnover to performance is one way to access the quality of the corporate governance within a firm or within a country. The reason is, in Kaplan (1994b)'s words, that "successful or efficient governance systems penalize managers of firms with poor stock performance and with particularly low cash flows." This statement is supported by large international evidence. ${ }^{5}$ Hence, the basic empirical prediction to be tested in this paper is the following.

Basic Hypothesis: Top executive turnover is negatively related to performance in Italian firms.

If the basic hypothesis is verified on the whole sample, the second step is to study whether there are significant differences across firms. An important factor that may affect turnover is the ownership structure of a firm.

\subsection{Ownership and control structure}

\footnotetext{
${ }^{4}$ The results suggests an interesting one-to-one correspondence between sensitivity of turnover to performance and market to book ratio.

${ }^{5}$ The first studies on US data are Coughlan and Smith (1985), and Warner, et al. (1988); on Japan, Kaplan (1994a) and Kang and Shivdasani (1995); on Germany, Kaplan (1994b), and Franks and Mayer (2000); on the UK, Franks, et al. (2000); on Belgium, Renneboog (2000).
} 
Firms on the Italian stock market can be classified into four large categories according to their ultimate owner: the State, a foreign company, a set of banks and one or more Italian individuals (I define this last category as family-controlled firms). We may expect differences across these groups in the sensitivity of turnover to performance. For example, in State-controlled companies management turnover may be affected by political more than economical factors. I first check whether there are differences across these categories. However, in order to use a homogeneous and significantly large set of observations, I focus the rest of the analysis on the set of firms that are controlled by Italian individuals.

Within this category, there may be significant differences across firms depending on the relationship between the management and the controlling shareholder of the firm. Denis and Denis (1994) find that in the US majority-owned firms experience significantly lower turnover, for given performance, than widely-held ones. Also, they find that in the majority-owned firms the controlling shareholder typically sits as top executive of the firm. Consistent with the result above, Denis, et al. (1997) find that the probability of top executive turnover (and the sensitivity of turnover to performance) is negatively correlated with the ownership stake held by officers. Most Italian traded companies are majority owned. Moreover, the size of the private benefits of control is extremely large in Italy, as shown by Zingales (1994) and Bianco et al. (1997). It is possible that the controlling shareholder is entrenched as a top executive against the interest of the other shareholders, in order to preserve his ability to extract those benefits. Hence, the first main hypothesis to test is the entrenchment hypothesis.

Entrenchment Hypothesis: Top executive turnover is lower and less sensitive to performance if the executives are controlling shareholders.

In Italy, the separation between ownership and control is enhanced by the widespread use of traded pyramids and non-voting shares. The sensitivity of turnover to performance may be proportionate to the fraction of cash flow rights owned by the controlling shareholder. One immediate rationale for this hypothesis is that monitoring the management may come at a cost. Hence, the higher the fraction of cash flow rights owned by the controlling shareholder, the larger the controlling shareholder's incentive to monitor the management. An alternative explanation is that the controlling shareholder has full incentives to monitor the management but enjoys both the security benefits and the private 
benefits of control. In this case, he chooses to replace a manager when the sum of the two benefits is small. When the controlling shareholder owns a larger stake in the company, the size of the security benefits affects to a larger extent his decision to replace a manager. Hence, performance, which measures security benefits, should be more important in explaining turnover the higher the fraction of cash-flow rights owned by the controlling shareholder. ${ }^{6}$

Incentive Hypothesis: Top executive turnover is more sensitive to performance if the controlling shareholder owns a larger fraction of income rights.

In about 15 percent of Italian traded companies, a coalition of important shareholders helps the controlling party control the company. These shareholders are kept together by explicit agreements to vote together, which are called voting syndicates ("sindacati di voto"). ${ }^{7}$ A voting syndicate can decide on its actions either unanimously or by majority rule. According to law experts (see Galgano, 1997) these agreements are legally binding only in the former case. It is important to notice that the degree of entrenchment of the controlling shareholder could be much lower if he needs a voting syndicate to control the firm. With a voting syndicate, the controlling shareholder does not have a lock on control and control is partially contestable.

An example is given by the turnover in Olivetti in 1996 (Il Sole 24 Ore, September 4 1996). Carlo De Benedetti, the long-time Chairman and President of the Board, was the relative majority shareholder in Olivetti with 15 percent of the voting rights. Thanks to a voting syndicate he controlled another 25 percent of the votes. In January 1996, after several years of very poor performance at Olivetti, the voting syndicate broke down and in September of the same year De Benedetti was forced to step down from all executive roles in the company. This case suggests that executive turnover is more sensitive to performance if the controlling shareholder does not have absolute control over the company, that is in the instances where there exists a voting syndicate (or a large

\footnotetext{
${ }^{6}$ I will not be able to evaluate directly the relative strength of the two explanations. The evidence that in firms at the bottom of the pyramid turnover is high and uncorrelated to performance may be viewed as in favor of the second interpretation.

${ }^{7}$ There is another type of agreement, called "sindacato di blocco", which binds the participants not to sell their shares.
} 
outside blockholder). ${ }^{8}$ However, it is also conceivable that voting syndicates sustain collusive agreements among large families aiming at preserving the stability of control. In this second case, voting syndicates do not necessarily increase turnover or the sensitivity of turnover to performance.

For the US, Denis, et al. (1997) show that the probability of top executive turnover is positively correlated to the presence of an outside blockholder.

Outside Monitoring Hypothesis: Top executive turnover is higher and more sensitive to performance in cases where there are outside blockholders and/or voting syndicates.

An alternative way to test the quality of the corporate governance within a firm is to look at the valuation of the firm. For the US, Morck, et al. (1988) and McConnell and Servaes (1990) find a non-linear relationship between $\mathrm{Q}$ and managerial ownership.

If the absence of sensitivity of turnover to performance is an indicator of bad governance, this should be reflected in the firm's valuation. Hence, I will test the following hypotheses on the Q-ratio.

Entrenchment Hypothesis: $Q$ should be lower if the executives are controlling shareholders.

Incentive Hypothesis: $Q$ should be higher if the controlling shareholder owns a larger fraction of income rights.

Outside Monitoring Hypothesis: $Q$ should be higher where there are outside blockholders and/or a voting syndicate.

\subsection{Other tests of the effectiveness of a governance structure}

In this section, I will consider other tests of the relationship between turnover and performance suggested by the literature.

\section{1) Post-turnover performance:}

\footnotetext{
${ }^{8}$ Pagano and Roell (1998) argue that large minority shareholders may have a role in monitoring the controlling shareholder.
} 
An alternative way to test the relationship between turnover and performance is to look at the firm's performance in the years following a radical turnover of the top executive team. Denis and Denis (1995) find that, in the US, performance improves significantly after a turnover. I will test whether this is true in the Italian sample.

\section{2) Transfers of control:}

Martin and McConnell (1991), for the US, and Franks and Mayer (1996), for the UK, find that turnover is higher following takeovers, whether hostile or friendly. ${ }^{9}$ Barclay and Holderness (1991), for the US, and Franks, et al. (2000) for the UK, find that a similar increase in turnover follows block trades. Italian firms typically have a controlling shareholder. A sale of the controlling stake is a simple proxy for a change in the firm's ownership structure and should be associated with an increase in the top executive turnover. However, since the sale can only happen with the consent of the controlling shareholder, takeovers in Italy may have a more limited disciplinary role than in the US or UK.

Gilson (1989), for the US, and Franks, et al. (2000), for the UK, find that turnover is higher in firms at the onset of a financial crisis, when the firm's creditors increase their pressure on the management and seize control. Transfer of the control to creditors should then be associated with an increase in the top executive turnover in the Italian sample.

An interesting example is the case of the Ferruzzi Group analyzed by Penati and Zingales (1996). In 1993, at the announcement that the group was unable to repay its debt, the largest creditors (the five largest Italian banks) took control of all companies belonging to the group and immediately replaced all the executives linked to the Ferruzzi family. The debt-restructuring plan was then designed and voted on, and the entire group was rescued in a few months. However, according to Penati and Zingales, the large banks that controlled the restructuring enjoyed large private benefits of control and did not maximize the payoff of all banks involved. Moreover, the banks did not act preventively, that is, before the financial crisis exploded.

\section{3) Structure of the board of directors:}

\footnotetext{
${ }^{9}$ Franks and Mayer (1996), for the UK, find a significantly higher turnover after hostile than after friendly takeovers; Martin and McConnell (1991), for the US, find no significant difference between the two.
} 
Weisbach (1988), for the US, and Kaplan and Minton (1994), for Japan, find that outside (nonexecutive) directors increase the sensitivity of turnover to performance. ${ }^{10}$ According to a survey (Crisci and Tarizzo, 1995) conducted in 1994 on the Boards of Directors of 500 Italian companies, $83 \%$ of the directors stated that they were on the board to represent the controlling shareholder's interest, and only $12 \%$ said that they were representing minority shareholders. This evidence questions the hypothesis that non-executive directors may play a disciplinary role in relation to executives in Italian firms.

\section{Description of the data-set}

The sample has been collected from several issues of "Il Taccuino dell'Azionista", an annual publication edited by Il Sole24Ore. This source provides basic balance sheet data, information about the ownership structure, and the names of the individuals sitting on the Board of Directors ("Consiglio di Amministrazione") of all companies traded on the Italian stock market. Data have been collected for a period of 12 years, from 1986 to 1997. From the set of all companies traded on the Milan Stock Exchange over that period, I have excluded banks, insurance companies and foreign companies. ${ }^{11}$ Moreover, I could not use the first and last observations for each company because of the definition of performance and turnover, as is explained below.

Hence, the sample used in the regressions covers ten years, 1987-1996, and contains a total of 1611 observations from 205 firms. Table 1 reports summary statistics on firms' characteristics, ownership structure, board composition and executive turnover for this sample.

Starting with the firms' characteristics, size is measured as the logarithm of the book value of total assets (which is measured in million Liras). Performance in year $\mathrm{t}$ is the change in the ratio of earnings before interest and taxes (EBIT) and total assets between $\mathrm{k} 1$ and $\mathrm{t}$. This measure of performance is the same one used in Denis and Kruse (2000). As a robustness check, I have tried alternative measures of performance: in particular, the annual stock return and a dummy variable that takes value one when companies report negative income. I do not report the results using these

\footnotetext{
${ }^{10}$ Franks and Mayer (2000) find that outside directors representing banks increase the sensitivity of turnover to performance in Germany.

${ }^{11}$ Foreign companies ae firms whose headquarters are abroad, while foreign-controlled companies are firms whose headquarters are in Italy, even though they are owned by foreigners. The latter ones are included in the sample.
} 
different measures since the results do not change substantially. I also performed the analysis with the addition of lagged performance without finding any difference.

With regard to the ownership structure, Italian law limits the extent of cross-holdings to 1 percent (for traded companies) and 2 percent (for non-traded ones). Hence, it is simple to identify the control chain once ownership data are available for all companies. An example of a typical control structure is represented in Figure 1. It shows the structure of the Pesenti group at the end of 1995. The Pesenti family is defined as the controlling shareholder because an individual, Rosalia Radici Pesenti, owns the controlling stake in the holding company (44.87 percent). ${ }^{12}$

The observations have been classified into four categories according to the information available on the controlling shareholder. A firm is classified as foreign-controlled in a given year if the ultimate owner is a foreign company (106 observations); and is defined as state-controlled if the ultimate owner is the State or a government agency (216 observations). In 55 observations the controlling party is a group of banks, since the company defaulted and the banks took control. The rest of the observations (1234) have one or more private Italian citizens or an Italian family as the ultimate owner (I will call this last set family-controlled firms).

In Table 1, three variables describe the firm ownership structure. The fraction of cash flow rights owned by the largest shareholder is defined as the product of the fraction of voting rights along the controlling path. This number is corrected for non-voting shares by assuming that the ultimate owner owns none of them. For example in Figure 1, the fraction of cash flow rights owned by the Pesenti family in Italmobiliare is 29.4 percent, while the fraction of voting rights is 44.8 percent because about a third of Italmobiliare's equity is made up of non-voting shares. The fraction of cash flow rights owned by the Pesenti family in Italcementi is 9.5 percent, which is the product of 29.4 percent (the fraction of cash flow rights directly owned by the family in the holding company Italmobiliare) and 32.4 percent (the fraction of cash flow rights owned by Italmobiliare in Italcementi). The fraction of voting rights controlled by the controlling shareholder is computed as the minimum share of voting rights controlled by the controlling shareholder along the control path. For example, in Figure 1 the fraction of voting rights owned by the Pesenti family in Italcementi is shown as 44.8 percent rather than 54.3 percent, which is the fraction of voting rights owned by

\footnotetext{
${ }^{12}$ From data provided by the Consob (the Italian equivalent of the Security Exchange Commission in the US), which are available only for the period 1995-1997, I also know that the ownership by Rosalia Radici Pesenti of 44.87 percent of Italmobiliare is indirect, that is, via a non-traded financial company.
} 
Italmobiliare in Italcementi. This is because the Pesenti family owns only 44.8 percent of the voting rights in Italmobiliare, which is a company along the controlling path of Italcementi. In the case of a syndicate among shareholders, the controlling party is assumed to control all the voting rights that belong to the syndicate. Finally, ownership change is a dummy variable that takes value 1 in year $\mathrm{t}$ for firm $i$, if there is a transfer of the controlling stake of firm $i$ between year $t$ and year $t+1$.

Board composition is characterized by the number of directors, the number of top executives (Presidente, Vice-Presidente, and Amministratori delegati) and the fraction of non-executive directors. The latter variable is defined as the ratio of the number of directors with no executive role in the firm (according to the source) over the total number of directors.

There are two are the measures of executive turnovers: the fraction of CEOs and the fraction of top executives replaced between $\mathrm{t}$ and $\mathrm{t}+1$. The variable used in the analysis is called Top executive turnover and is a dummy variable that is equal to 1 in year t for firm $\mathrm{i}$ if at least half of the top executives of firm i change between year $t$ and year $t+1$. I have chosen to focus on this measure of turnover (Top executive turnover) because Presidente, Vice-Presidente, and Amministratori delegati have similar executive power and there is no clear ranking among them. Moreover, using Top executive turnover reduces the distortions due to incorrect measurements of turnover. Indeed, all measures of turnover have been cleaned of the cases of retirement identifiable through LEXISNEXIS. ${ }^{13}$ However, Italian companies do not provide information about the age of their executives in the annual report. Since I was able to collect data on age for only a small number of them, I am excluding age from the regressions. Using the dummy variable Top executive turnover as measure of turnover has the advantage of minimizing the potential distortions due to incorrectly including turnover due to age.

From Table 1, all companies in the sample have a controlling shareholder, that is, a shareholder who controls a fraction of voting rights larger than 20 percent. ${ }^{14}$ The fraction of voting rights is on average 56 percent, while it ranges between 20.1 percent and 100 percent. Disciplinary turnover (measured either as CEO or as Top executive turnover) happens in 15 percent of the observations. The average size of the board is 10 directors. The fraction of non-executive directors is larger that in the US, being, on average, 60 percent. There is a large variability in the fraction of cash flow rights

\footnotetext{
${ }^{13}$ There are 42 observations relabeled as non-turnover in this way.

${ }^{14}$ The 20 percent threshold for control is the most restrictive one used by La Porta, et al. (1999).
} 
owned by the controlling shareholder. The average is 40 percent, while the minimum is 0.3 percent and the maximum 99.4 percent.

\section{Empirical analysis}

In this section, I will test each of the hypotheses discussed in section 2, starting with the relationship between turnover and performance for the whole sample.

\subsection{Analysis of the whole sample}

In Table 2, the observations are classified on the basis of the ultimate owner in family-, state-, foreign- and bank-controlled firms. The table shows that turnover is negatively related to performance in the sample as a whole. More precisely, overall, the change in the ratio of EBIT and assets between $\mathrm{t}-1$ and $\mathrm{t}$ is significantly smaller than zero if there is a turnover between $\mathrm{t}$ and $\mathrm{t}+1$, and larger than zero otherwise. However, when I distinguish for the types of ultimate owner, no significant relationship between turnover and performance is found in state-, foreign- and bank-controlled firms.

This result is confirmed in Table A1 of the Appendix. The regression reported in the table describes the relationship between turnover and performance after controlling for the firm's size and number of top executives. Interactive dummies allow for different coefficients across the types of ultimate ownership and chi-square tests (at the bottom) evaluate whether turnover is significantly affected by performance in state-, foreign- and bank-controlled firms. In family-controlled firms, the relationship between turnover and performance is strongly significant and negative. In statecontrolled firms the relationship is negative but barely significant: the test of the hypothesis $(a)+(b)=0$, at the bottom of the table, rejects the hypothesis at a 10 percent significance level. Turnover is not significantly related to performance with the other types of ultimate owner.

In the rest of the paper I will restrict my attention to the set of family-controlled firms in order to have a large and homogeneous sample.

\subsection{Family-controlled firms: descriptive statistics}

Table 3 provides detailed information on the subset of family-controlled firms. I have divided the observations into four categories according to their ownership structure: (1) stand-alone firms and firms that belong to horizontal groups (that is, firms that are not controlled by any other traded company and do not own a controlling stake in any other traded company); (2) firms that are at the 
top of a pyramidal group (that is, firms that are not controlled by any other traded company and do control at least one other traded company); (3) firms that are at level 2 of a pyramidal group (that is, firms that are directly controlled by a company of type 2); and (4) firms that are at level 3 or higher of a pyramidal group (that is, firms that are controlled - directly or indirectly - by a company of type 3). The table provides the mean of several variables conditional on the type of ownership structure.

About 55 percent of the observations in the sample come from pyramidal groups. The rest of the firms in the sample belong to horizontal groups (42 observations only) or are stand-alone firms (all the rest). The first impact of the pyramidal structure is to create a wedge between the fraction of cash-flow and voting rights owned by the controlling shareholder. As shown in Table 3, the separation of voting and cash-flow rights (as measured by the ratio of voting to cash-flow rights) increases from 1.4 at the top of the pyramid, to 7 at the bottom of it. ${ }^{15}$ Table 3 tries to evaluate the consequences of this separation of ownership from control.

The first candidate is top executive turnover. I find that turnover is significantly lower at the top of pyramidal groups than in all other firms: at the top of a pyramid, the probability that at least half of the executives are replaced in one year is less than 6 percent. Moreover, when I look at the sensitivity of turnover to performance, I find that turnover is unaffected by performance at the top of a pyramid. The combination of these two results suggests that top executives at the top of pyramidal groups are entrenched. Table 3 suggests that this happens because the controlling shareholders of the group are very likely to sit as top executives in the holding company at the top of the pyramid. ${ }^{16}$

Interestingly, I also find that turnover is independent of performance at the bottom of a pyramid. Since, at the lower layers of a pyramid turnover is high (about 16 percent), this results suggests that there may be excessive turnover in those firms. One possible explanation is that the management of subsidiaries is replaced after good performance and promoted to higher layers of the pyramidal group. In order to address this concern, I have relabeled as non-turnover all cases in which an executive leaves a company to move to another traded company within the same group. I will refer

\footnotetext{
${ }^{15}$ The difference between voting and cash-flow rights in categories (1) and (2) is due to non-voting shares (azioni di risparmio) and voting syndicates.

${ }^{16}$ I classified the top executives depending on whether they belonged to the family of the controlling shareholder. To do so, I have searched the Lexis -Nexis database for each executive in the sample to find his relationship with the controlling shareholder. For example, in Figure 1, only one of the Pesenti's executives belongs to the Pesenti family: Giampiero Pesenti, son of the controlling shareholder, Rosalia Radici Pesenti.
} 
to this variable as modified top executive turnover. The table suggests that turnover according to this measure is significantly lower, but is still independent of performance at the top and at the bottom of the pyramid. Hence, I find some support of the hypothesis that the higher turnover at the bottom of the pyramid is due to dynamics in the internal managerial market. Moreover, the results on the sensitivity of turnover to performance are confirmed even with this alternative measure of turnover. ${ }^{17}$

From Table 3, we can also address the issue of whether the absence of sensitivity of turnover to performance is reflected in a lower valuation by the market. Indeed, the table shows that companies at the top and at the lowest layers of the pyramid have lower $\mathrm{Q}{ }^{18}$

The table also shows that the voting premium is higher at the top than at lower layers of the pyramid. This suggests that the reason why controlling shareholders entrench themselves as executives of the holding companies is to enjoy higher private benefits of control.

The coming sections will expand on the discussion above and provide more careful tests of the hypotheses formulated in section 2 .

\subsection{Turnover and control}

Table 4 studies the impact of the separation of ownership and control on turnover. For these purposes, I have created two dummy variables. The first one (controlling shareholder - manager) identifies the cases in which the controlling shareholder sits as top executive of the firm. In particular, to be consistent with the definition of turnover, this dummy variable is set equal to 1 when at least half of the top executives belong to the family of the controlling shareholder. This happens in about 30 percent of the observations. The purpose of this first dummy variable is to address the Entrenchment Hypothesis described in section 2. The second dummy variable (controlling shareholder with high incentives) identifies the companies in which the controlling shareholder owns a large fraction of the cash-flow rights. More specifically, I have defined those as companies in which the controlling shareholder owns more than 50 percent of the cash flow rights, a requirement that roughly selects 30 percent of the observations. The purpose of this second dummy variable is to address the Incentive Hypothesis.

\footnotetext{
${ }^{17}$ An important caveat is that I cannot control for cases in which the manager moves to a non-traded company that belongs to a group, because I do not have data on non-traded firms.

${ }^{18} \mathrm{Q}$ is computed as the sum of the market value of equity and the book value of debt, divided by the book value of total assets. The results do not change when I use the market-to-book ratio instead than the Q.
} 
The results in Table 4 are as follows. Regression (1) shows that turnover decreases with performance. However, regression (2) shows that this is not true when the controlling shareholder sits as top executive of the firm, as shown by the fact that the test of the hypothesis (a)+(b)=0 cannot be rejected, even at a 10 percent significance level. This result is in favor of the Entrenchment Hypothesis. Regression (3) shows that the sensitivity of turnover to performance increases, even if not significantly, when the controlling shareholder owns a large stake in the firm. This is partially in favor of the Incentive Hypothesis. In order to evaluate the strength of the two forces, regression (4) includes both dummies as interactive terms. The result is that the entrenchment effect is stronger than the incentive one. Indeed, the test at the bottom of the table does not reject the hypothesis that (a) $+(b)+(c)=0$. This suggests that controlling shareholders are entrenched even when their exposure to the firm's cash flows is large. On the other hand, regression (4) shows that the incentive effect increases the sensitivity of turnover to performance significantly when the management does not belong to the controlling shareholder's family. This result supports the Incentive Hypothesis.

According to the Outside Monitoring Hypothesis discussed in section 2, turnover should be more sensitive to performance when the company has large minority shareholders. The intuition is that large minority shareholders may play an active role in corporate governance. This hypothesis is tested in Table 5 by using two proxies for minority shareholders. The first is an indicator of whether the second largest shareholder owns a fraction larger than 5 percent of the voting rights. This happens in about 40 percent of the observations. The second identifies cases where the firm is controlled by a voting syndicate, as happens in 15 percent of the observations. Regressions (1) and (2) suggest that the presence of a large minority shareholder does not increase the sensitivity of turnover to performance. However, regression (3) shows that a voting syndicate does indeed increase the sensitivity of turnover to performance. Finally, regression (4) shows that even controlling shareholders are less entrenched, when a voting syndicate controls a company. Indeed, a chi-square test at the bottom of the table rejects the hypothesis that $(a)+(c)+(d)=0$ at a 5 percent significance level. The intuitive explanation for the result in Table 5 is that minority shareholders have the power to play a governance role (and they do so) only when control is not locked in the hands of the controlling shareholder, that is, only if the controlling shareholder needs a voting syndicate to control the firm.

In Table 6, the analysis in Table 4 is repeated with the variable modified top executive turnover that redefines as non-turnover all the cases in which the executive leaves the firm but moves to an 
executive position in another traded company of the group. The results do not change in any significant way from those in Table 4. This confirms the evidence on the entrenchment and incentive hypotheses.

\subsection{Valuation}

An alternative way to assess the efficiency of a governance structure is to evaluate the impact of ownership structure on a firm's valuation, as done by Morck, et al. (1988) and McConnell and Servaes (1990). This analysis is performed in Table 7.

The results on $\mathrm{Q}$ match one to one those obtained in the analysis of turnover: firms where turnover is unaffected by performance are discounted by the market. Indeed, Table 7 shows that $\mathrm{Q}$ is significantly smaller (a 9 percent discount in regression 3) for firms in which controlling shareholders are among the top executives. This is consistent with the results in Table 4 and with the Entrenchment Hypothesis. Table 7 also shows that Q is significantly larger when control is partially contestable as in the case in which a voting syndicate controls the firm (a 31 percent premium). This result is consistent with the findings in Table 5 and with the Outside Monitoring Hypothesis. Finally, the table shows that $\mathrm{Q}$ increases with the fraction of cash-flow rights owned by the controlling shareholder. Q increases by 2 percent for any 10-percent increase in the fraction of cash-flow rights owned by the controlling shareholder. This final result supports the Incentive Hypothesis.

\subsection{Other tests}

A further test of the relationship between turnover and performance is to check whether top executive turnover really increases performance. In Table 8 the observations are classified into two categories: Turnover and No Turnover, according to whether there is a top executive turnover in firm $\mathrm{i}$ between year $\mathrm{t}$ and year $\mathrm{t}+1$, or not. Then, for both sets of observations, ante-event performance (defined as the change in EBIT/TA between $\mathrm{t}-1$ and $\mathrm{t}$ ) and post-event performance (defined as the change in EBIT/TA between $\mathrm{t}+1$ and $\mathrm{t}+2$ ) are computed. The table shows that past performance is significantly negative for companies that undergo a top executive turnover in year $t$, and not for the other companies. On the other hand, future performance is not significantly different for companies subject to a top executive turnover, while it is slightly negative for the other companies. This result is similar to the one in Denis and Denis (1995) and suggests that turnover improves performance. 
Table 9 addresses the relationship between turnover and changes in the identity of the controlling shareholder. Panel A shows that turnover increases considerably when companies change their controlling shareholder. When there is a sale of the controlling stake, turnover increases to a 65 percent average from a 9 percent average when the company is not subject to a change in control. When the control shifts to creditors, turnover increases to 52 percent. In both cases, the increase is statistically significant. Furthermore, no significant difference is found between the amount of turnover when there is a sale of the control and when creditors take over. Panel A also shows that changes in control (both sales and creditors' takeovers) are sgnificantly more likely if the company's past performance has been poor. In Panel B, I focus on each of the three groups separately (sales of controlling stake, creditors' takeovers, and none of the above), to evaluate the sensitivity of turnover to performance in each of the cases. In all cases but regular transfers of control, turnover is associated with significantly worse past performance.

These results are along the lines of the evidence in Martin and McConnell (1991) and Gilson (1989) for the US. They suggest that transfers of control play some governance role in Italy. A minor difference from the results on the US sample is that sales of the controlling stake are associated with executive turnover independently of the company's past performance. In the US, turnover after a takeover is more likely the worse is past performance.

To evaluate the role of non-executive directors, I have distinguished between companies with boards with a fraction larger than 65 percent of non-executive directors. ${ }^{19}$ In regressions (1) and (2) in Table 10, I find that outsider-dominated boards do not increase the sensitivity of turnover to performance. Rather, the opposite may be true. Similarly, in regressions (3) and (4) the sensitivity of turnover to performance is not affected by the size of the board. ${ }^{20}$

\section{Conclusion}

This paper provides direct evidence of the inefficiencies that arise from a governance structure characterized by low legal protection for investors, firms with large controlling shareholders and some separation of ownership and control created via pyramidal groups. Studying Italy, a country that has all the features of such a governance structure, I find that turnover is significantly lower and

\footnotetext{
${ }^{19}$ About 35 percent of the observation falls into this category.

${ }^{20}$ According to Yermack (1996), small boards are more efficient.
} 
unaffected by performance when controlling shareholders sit among the top executives. This result is evidence that controlling shareholders are entrenched. I also find that turnover is more sensitive to performance the larger is the fraction of cash flow rights owned by the controlling shareholder. This second result suggests that governance improves when the controlling shareholder's objectives are more aligned with those of minority shareholders. The third result of the analysis is that turnover is more sensitive to performance when control is, to some extent, contestable, as in the case of a voting syndicate. Moreover, in this case, I find that even the controlling shareholder (that is, the largest shareholder in the voting syndicate) is more likely to be replaced after a bad performance.

These findings are confirmed by an analysis of the firms' Q. I find that Q increases with the fraction of cash-flow rights owned by the controlling shareholder, is significantly smaller for firms in which controlling shareholders are among the top executives, and is significantly larger when a voting syndicate controls the firm.

The combined results on executive turnover and $\mathrm{Q}$ suggest a one-to-one correspondence between bad governance (that is, low sensitivity of turnover to performance) and low valuation (that is, low Q).

The paper also provides results on pyramidal groups. Within pyramidal groups, I find that turnover is independent of performance both at the top (in the holding companies) and at the bottom (in the subsidiaries of level 3 and higher) of a pyramid. In the holding company turnover is very low, while in the subsidiaries turnover is relatively high. The first result suggests that executives at the top of the pyramid are entrenched. This may be so because the controlling shareholders of the group sit as executives of their holding companies and the benefits of control are larger in the holding company, as suggested by the finding that the voting premium in the holding companies is significantly larger than in the subsidiaries. Regarding the executive turnover at the bottom of the pyramid, a possible explanation is that good managers are promoted to a higher level of the pyramidal group. I find some support for this interpretation when I redefine turnover as a situation in which the executive leaves the traded part of the group, rather than just the firm.

To conclude, what can be done to improve corporate governance in a country like Italy? The finding that voting syndicates increase the sensitivity of turnover to performance and improve the firm's Q suggests that the creation of a more competitive and active market for corporate control may be the answer. Indeed, the paper finds that turnover increases substantially after a transfer of the controlling stake and that transfers of control are more likely if the firm's past performance has been 
worse. However, an effective market for corporate control requires control to be contestable, because otherwise control can be transferred only with the consent of the controlling shareholder or if the company defaults. According to Bebchuk (1999) large shareholders stay firmly in control wherever control is extremely valuable. Ultimately, as argued by La Porta, et al. (1999), control is valuable because low legal protection for investors enables the controlling shareholder to enjoy large private benefits of control. Hence, this suggests that the solution lies at a political level in new legislation to improve the quality and the enforcement of investor protection. 


\section{References}

Barca F., 1994. Assetti proprietari e mercato delle imprese. Volume I. e II. Il Mulino, Bologna.

Barclay, M., Holderness, C., 1991. Negotiated block trades and corporate control. Journal of Finance 46, 861-878.

Bebchuk, L., 1999. A rent-protection theory of corporate ownership and control. Working paper N.B.E.R. no. 7203.

Bebchuk, L., Kraakman, R., Triantis, G., 1998. Stock pyramids, cross-ownership, and dual class: The creation and agency costs of separation between control and cash flows rights. Working paper N.B.E.R. 6951.

Bianco, M., Casavola, P., Ferrando, A., 1997. Pyramidal groups and external finance: An empirical investigation. Unpublished working paper, Bank of Italy.

Coffee, J., 1999. The future as history: The prospects for global convergence in corporate governance and its implications. Northwestern University Law Review 93, 641-708.

Coughlan, A., Schmidt, R., 1985. Executive compensation, managerial turnover, and firm performance: An empirical investigation. Journal of Accounting and Economics 7, 43-66.

Crisci, G., Tarizzo, G., 1995. Il governo dell'impresa: Il ruolo dei C.d.A. nelle aziende italiane. Le Società 5, 607-616.

Denis, D., Denis, D., 1994. Majority owner-manager and organizational efficiency. Journal of Corporate Finance 1, 91-118.

Denis, D., Denis, D., 1995. Performance changes following top managerial dismissals. Journal of Finance 50, 1029-1057.

Denis, D., Denis, D., Sarin, A., 1997. Ownership structure and top executive turnover. Journal of Financial Economics 45, 193-221.

Denis, D., Kruse, T., 2000. Managerial discipline and corporate restructuring following performance declines. Journal of Financial Economics 55, 391-424.

Franks, J., Mayer, C., 1996. Hostile takeovers in the UK and the correction of managerial failure. Journal of Financial Economics 40, 163-181. 
Franks, J., Mayer, C., 2000. Ownership and control of German corporations. Unpublished working paper, London Business School, forthcoming in the Review of Financial Studies.

Franks, J., Mayer, C., Renneboog, L., 2000. Who disciplines management in poorly performing companies? Unpublished working paper, London Business School.

Galgano, F., 1997. Diritto commerciale. Zanichelli, Bologna.

Gilson, S., 1989. Management turnover and financial distress. Journal of Financial Economics 25, 241-262.

Johnson, S., La Porta, R., Lopez-de-Silanes, F., Shleifer, A., 2000. Tunneling. American Economic Review Papers and Proceedings 90, 22-27.

Kang, J., Shivdasani, A., 1995. Firm performance, corporate governance, and top executive turnover in Japan. Journal of Financial Economics 38, 29-58.

Kaplan, S., Minton, B., 1994. Appointments of outsiders to Japanese boards: Determinants and implications for managers. Journal of Financial Economics 36, 225-258.

Kaplan, S., 1994. Top executive rewards and firm performance: A comparison of Japan and the United States. Journal of Political Economy 102, 510-546.

Kaplan, S., 1994. Top executives, turnover, and firm performance in Germany. Journal of Law, Economics \& Organization 10, 142-159.

La Porta, R., Lopez-de-Silanes, F., Shleifer, A., Vishny, R., 1998. Law and finance. Journal of Political Economy 101, 678-709.

La Porta, R., Lopez-de-Silanes, F., Shleifer, A., 1999. Corporate ownership around the world. Journal of Finance 54, 471-517.

Martin, J., McConnell, J., 1991. Corporate performance, corporate takeovers and management turnover. Journal of Finance 46, 671-687.

McConnell, J., Servaes, H., 1990. Additional evidence on equity ownership and corporate value. Journal of Financial Economics 26, 595-612.

Morck, R., Shleifer, A., Vishny, R., 1988. Management ownership and market valuation. Journal of Financial Economics 20, 293-315.

Nicodano, G., 1998. Corporate groups, dual-class shares and the value of voting rights. Journal of Banking and Finance 22, 1117-1137. 
Pagano, M., Roell, A., 1998. The choice of stock ownership structure: Agency costs, monitoring, and the decision to go public. Quarterly Journal of Economics 113, 187-275.

Penati, A., Zingales, L., 1996. Efficiency and distribution in financial restructuring: The case of the Ferruzzi group. Unpublished working paper, University of Chicago.

Renneboog, L., 2000. Ownership, managerial control and the governance of companies listed on the Brussels stock exchange. Journal of Banking and Finance 24, 1959-1995.

Shleifer, A., Vishny, R., 1997. A survey of corporate governance. Journal of Finance 52, 737-783.

Yermack, D., 1996. Higher market valuation of companies with a small board of directors. Journal of Financial Economics 40, 185-211.

Warner, J., Watts, R., Wruck, K., 1988. Stock prices, event prediction, and event studies: An examination of top management restructuring. Journal of Financial Economics 20, 461-492.

Weisbach, M., 1988. Outside directors and CEO turnover. Journal of Financial Economics 20, 431-460.

Wolfenzon, D., 1998. A theory of pyramidal ownership. Unpublished working paper, Harvard University.

Zingales, L., 1994. The value of the voting right: A study of the Milan stock exchange experience. Review of Financial Studies 7, 125-148. 
Table 1. Descriptive statistics: Whole sample.

The table reports the number of observations, the mean, median, standard deviation, minimum and maximum for the variables used in the analysis. The sample includes all companies traded on the Milan Stock Exchange, excluding banks, insurance and pure financial companies, in the years 1987-1996. The number of observations is 1611 for all variables.

\begin{tabular}{|c|c|c|c|c|c|}
\hline Variable & Mean & Median & Std. Dev & Min & Max \\
\hline \multicolumn{6}{|l|}{ Firm characteristics } \\
\hline Size (logarithm of total assets) & 13.4 & 13.2 & 1.63 & 9.0 & 18.6 \\
\hline $\begin{array}{l}\text { Performance (change in EBIT / Total } \\
\text { Assets between } t-1 \text { and } t \text { ) }\end{array}$ & 0.001 & 0.002 & 0.061 & -0.48 & 0.54 \\
\hline \multicolumn{6}{|l|}{ Ownership structure } \\
\hline $\begin{array}{l}\text { Fraction of cash flow rights owned by } \\
\text { controlling shareholder }(\%)\end{array}$ & 38.0 & 40.5 & 25.0 & 0.3 & 99.4 \\
\hline $\begin{array}{l}\text { Fraction of voting rights controlled by } \\
\text { controlling shareholder }(\%)\end{array}$ & 56.4 & 53.8 & 14.7 & 20.1 & 100 \\
\hline Ownership change & 0.05 & 0 & 0.22 & 0 & 1 \\
\hline \multicolumn{6}{|l|}{ Board composition } \\
\hline Number of directors & 10.4 & 10 & 3.3 & 3 & 25 \\
\hline Fraction of non-executive directors $(\%)$ & 59.8 & 61.5 & 13.0 & 0 & 90.0 \\
\hline Number of top executives & 3.34 & 3 & 0.68 & 1 & 6 \\
\hline \multicolumn{6}{|l|}{ Turnover data } \\
\hline Fraction of CEOs being replaced (\%) & 13.8 & 0 & 33.5 & 0 & 100 \\
\hline $\begin{array}{l}\text { Fraction of top executives being replaced } \\
(\%)\end{array}$ & 16.9 & 0 & 25.3 & 0 & 100 \\
\hline $\begin{array}{l}\text { Top executive turnover (indicator of } \\
\text { turnover of at least half of the top } \\
\text { executives) }\end{array}$ & 0.14 & 0 & 0.35 & 0 & 1 \\
\hline
\end{tabular}


Table 2. Turnover and performance: Family-, state-, foreign- and bank-controlled firms.

The table illustrates the relationship between top executive turnover and performance for each of the four types of ultimate owner (a family, the state, a foreign company, a bank). The average (above), the median (below) performance and the number of observations (on the right) are reported for companies subject to a turnover and not. Performance is measured by the change in EBIT/Total Assets between $\mathrm{t}-1$ and $\mathrm{t}$. Turnover is a dummy variable that takes value 1 if at least half of the top executives are replaced between $t$ and $t+1$. Significance of means and medians is measured using a two-tailed t-test and a two-tailed Wilcoxon signed rank test, respectively. $*, * *$, and $* * *$ denote significance at the 10,5 , and 1 percent level, respectively.

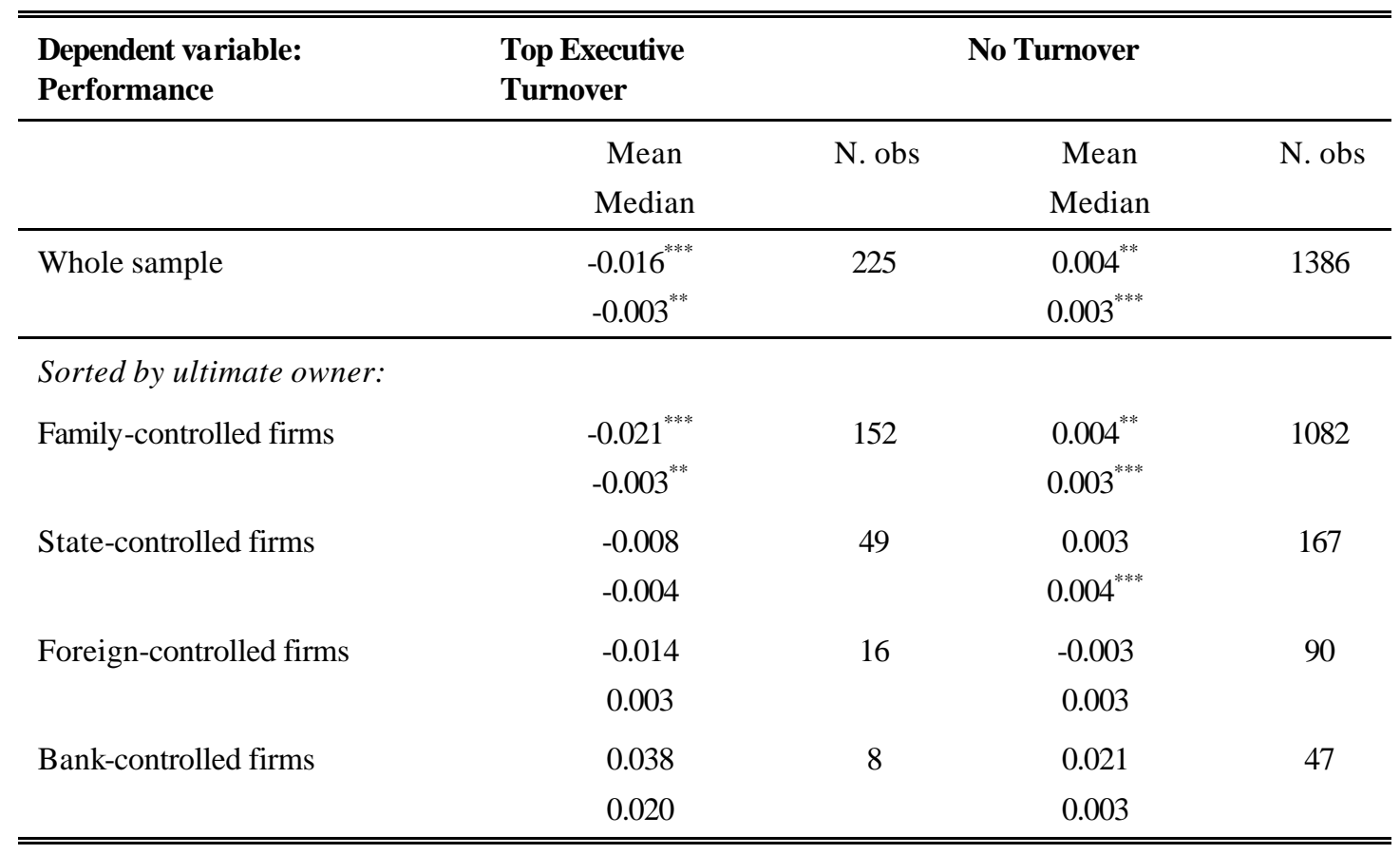




\section{Table 3. Separation of ownership from control in family-controlled firms.}

The table reports conditional means, unless specified otherwise. The observations are classified into four categories according to the structure of control. Top executive turnover is a dummy variable that takes value 1 in year $t$ if at least half of the top executives are replaced between $t$ and $t+1$. Modified top executive turnover is a dummy variable that takes value 1 in year $t$ if at least half of the top executives are replaced between $t$ and $t+1$ and leave all traded companies of the group to which the firm belongs. When explicitly stated, the significance levels of the means is reported: ***, and $* * *$ denote significance at the 10,5 , and 1 percent level, respectively.

\begin{tabular}{|c|c|c|c|c|}
\hline & $\begin{array}{l}\text { Horizontal } \\
\text { groups and } \\
\text { stand alone }\end{array}$ & $\begin{array}{l}\text { Pyramidal } \\
\text { group: } \\
\text { I.evel } 1 \\
\end{array}$ & $\begin{array}{l}\text { Pyramidal } \\
\text { group: } \\
\text { I evel } 2 \\
\end{array}$ & $\begin{array}{l}\text { Pyramidal } \\
\text { group: } \\
\text { I evel } 3+ \\
\end{array}$ \\
\hline Number of observations & 541 & 173 & 243 & 277 \\
\hline $\begin{array}{l}\text { Fraction of cash-flow rights owned by } \\
\text { controlling shareholder }(\%)\end{array}$ & 49.4 & 42.2 & 22.5 & 6.0 \\
\hline $\begin{array}{l}\text { Fraction of voting rights controlled by } \\
\text { controlling shareholder }(\%)\end{array}$ & 58.2 & 59.8 & 52.5 & 42.6 \\
\hline Top executive turnover (\%) & 12.0 & 5.8 & 14.0 & 15.5 \\
\hline $\begin{array}{l}\text { Correlation between turnover and } \\
\text { performance (with significance level) }\end{array}$ & $-0.218^{* * *}$ & 0.018 & $-0.122^{*}$ & -0.039 \\
\hline $\begin{array}{l}\text { Percentage of relatives of the controlling } \\
\text { shareholder among the top executives (\%) }\end{array}$ & 38.2 & 50.1 & 26.6 & 7.4 \\
\hline $\begin{array}{l}\text { Firm's } \mathrm{Q} \\
\text { (with significance level of test of the } \\
\text { hypothesis: } \mathrm{Q}=1 \text { ) }\end{array}$ & $1.13^{* * *}$ & 1.01 & $1.09^{* *}$ & 1.00 \\
\hline Voting premium (\%) & 77.2 & 70.2 & 59.5 & 32.5 \\
\hline [Number of observations] & [184] & [118] & [108] & [127] \\
\hline $\begin{array}{l}\text { Modified top executive turnover (cleaned } \\
\text { of cases in which the executive moves to } \\
\text { another comp any within the group) (\%) }\end{array}$ & 7.9 & 4.0 & 9.5 & 10.1 \\
\hline $\begin{array}{l}\text { Correlation between modified turnover } \\
\text { and performance (with significance level) }\end{array}$ & $-0.201^{* * * *}$ & 0.063 & $-0.155^{* *}$ & -0.039 \\
\hline
\end{tabular}


Table 4. Relationship between turnover and performance in family-controlled firms.

Probit regressions: $\Phi^{-1}\left(E\left(y_{i t}\right)\right)=\mathbf{x}_{i t} \beta$, where $y$ follows a binomial distribution and $\Phi^{-1}($.$) is the inverse of$ the cumulative gaussian distribution. The dependent variable (Top executive turnover) is a dummy variable that takes value 1 in year $\mathrm{t}$ if at least half of the top executives are replaced between $\mathrm{t}$ and $\mathrm{t}+1$. Size is the logarithm of total assets (in million Liras). Performance is the change in the ratio of EBIT and total assets between year t-1 and year t. There is a controlling shareholder manager when at least half of the top executives belong to the family of the controlling shareholder. Controlling shareholder with high incentives is a dummy variable that takes value 1 when the controlling shareholder owns a fraction larger than 50 percent of the firm's cash flow rights. Robust standard errors (in parenthesis) control for correlation and clustering at firm level. Year dummies are included but the coefficients are not reported. Chi-squared tests are reported at the bottom of the table to test whether the interactive terms are significant. *,**, and *** denote significance at the 10,5 , and 1 percent level, respectively.

\begin{tabular}{|c|c|c|c|c|}
\hline Number of top executives & $\begin{array}{r}0.167^{* *} \\
(.067)\end{array}$ & $\begin{array}{r}0.137^{* *} \\
(.070)\end{array}$ & $\begin{array}{r}0.167^{* *} \\
(.068)\end{array}$ & $\begin{array}{l}0.136^{* *} \\
(.071)\end{array}$ \\
\hline Size & $\begin{array}{r}-0.058^{*} \\
(.035)\end{array}$ & $\begin{array}{l}-0.055 \\
(.034)\end{array}$ & $\begin{array}{r}-0.063^{*} \\
(.037)\end{array}$ & $\begin{array}{l}-0.056 \\
(.036)\end{array}$ \\
\hline Performance (a) & $\begin{array}{r}-3.19^{* * *} \\
(.893)\end{array}$ & $\begin{array}{r}-3.62^{* * * *} \\
(.798)\end{array}$ & $\begin{array}{r}-2.35^{* * *} \\
(.901)\end{array}$ & $\begin{array}{r}-2.77^{* * *} \\
(.930)\end{array}$ \\
\hline $\begin{array}{l}\text { Performance } * \text { Controlling } \\
\text { shareholder - manager }(b)\end{array}$ & & $\begin{array}{r}1.20 \\
(2.03)\end{array}$ & & $\begin{array}{r}1.73 \\
(2.08)\end{array}$ \\
\hline $\begin{array}{l}\text { Performance } * \text { Controlling } \\
\text { shareholder with high incentives (c) }\end{array}$ & & & $\begin{array}{l}-2.17 \\
(1.84)\end{array}$ & $\begin{array}{l}-2.57^{*} \\
(1.56)\end{array}$ \\
\hline Controlling shareholder manager & & $\begin{array}{r}-0.399^{* * *} \\
\quad(.119)\end{array}$ & & $\begin{array}{r}-0.398^{* * *} \\
(.118)\end{array}$ \\
\hline $\begin{array}{l}\text { Controlling shareholder with high } \\
\text { incentives }\end{array}$ & & & $\begin{array}{r}-0.074 \\
(.108) \\
\end{array}$ & $\begin{array}{l}-0.016 \\
(.106) \\
\end{array}$ \\
\hline Pseudo $\mathrm{R}^{2}$ & 0.046 & 0.061 & 0.049 & 0.064 \\
\hline N. observations & 1234 & 1234 & 1234 & 1234 \\
\hline Test: $(a)+(b)=0$ & & 1.56 & & 0.31 \\
\hline Test: $(a)+(c)=0$ & & & $6.84^{* * *}$ & $17.6^{* * * *}$ \\
\hline Test: $(a)+(b)+(c)=0$ & & & & 2.00 \\
\hline
\end{tabular}


Table 5. Monitoring by large minority shareholders.

Probit regressions. The dependent variable (Top executive turnover) is a dummy variable that takes value 1 in year $\mathrm{t}$ if at least half of the top executives are replaced between $\mathrm{t}$ and $\mathrm{t}+1$. Size is the logarithm of total assets (in million Liras). Performance is the change in the ratio of EBIT and total assets between year t-1 and year t. Large minority shareholders is a dummy variable that takes value 1 when the second largest shareholder owns a fraction larger than 5 percent of the firm's voting rights. There is a controlling shareholder - manager when at least half of the top executives belong to the family of the controlling shareholder. Robust standard errors (in parenthesis) control for correlation and clustering at firm level. Year dummies are included but the coefficients are not reported. Chi-squared tests are reported at the bottom of the table to test whether the interactive terms are significant. *,**, and $* * *$ denote significance at the 10,5 , and 1 percent level, respectively.

\begin{tabular}{|c|c|c|c|c|}
\hline & (1) & (2) & (3) & (4) \\
\hline Number of top executives & $\begin{array}{r}0.172^{* *} \\
(.068)\end{array}$ & $\begin{array}{r}0.142^{* *} \\
(.071)\end{array}$ & $\begin{array}{l}0.166^{* *} \\
(.067)\end{array}$ & $\begin{array}{r}0.138^{* * *} \\
(.070)\end{array}$ \\
\hline Size & $\begin{array}{r}-0.063^{*} \\
(.035)\end{array}$ & $\begin{array}{r}-0.059^{*} \\
(.035)\end{array}$ & $\begin{array}{r}-0.057^{*} \\
(.036)\end{array}$ & $\begin{array}{r}-0.055 \\
(.035)\end{array}$ \\
\hline Performance (a) & $\begin{array}{r}-3.42^{* * *} \\
(1.18)\end{array}$ & $\begin{array}{r}-3.97^{* * *} \\
(1.09)\end{array}$ & $\begin{array}{r}-2.69^{* * *} \\
(1.00)\end{array}$ & $\begin{array}{r}-3.09^{* * *} \\
(.941)\end{array}$ \\
\hline $\begin{array}{l}\text { Performance } * \text { Large minority } \\
\text { shareholders }(b)\end{array}$ & $\begin{array}{l}0.737 \\
(2.06)\end{array}$ & $\begin{array}{l}0.945 \\
(2.04)\end{array}$ & & \\
\hline $\begin{array}{l}\text { Performance } * \text { Voting syndicate } \\
\text { dummy (c) }\end{array}$ & & & $\begin{array}{l}-3.01^{*} \\
(1.83)\end{array}$ & $\begin{array}{l}-2.49 \\
(1.84)\end{array}$ \\
\hline $\begin{array}{l}\text { Performance } * \text { Controlling } \\
\text { shareholder - manager }(\mathrm{d})\end{array}$ & & $\begin{array}{r}1.34 \\
(2.07)\end{array}$ & & $\begin{array}{l}0.819 \\
(2.01)\end{array}$ \\
\hline Large minority shareholders & $\begin{array}{r}-0.115 \\
(.108)\end{array}$ & $\begin{array}{r}-0.096 \\
(.108)\end{array}$ & & \\
\hline Voting syndicate dummy & & & $\begin{array}{l}-0.155 \\
(.151)\end{array}$ & $\begin{array}{r}-0.115 \\
(.149)\end{array}$ \\
\hline Controlling shareholder - manager & & $\begin{array}{r}-0.392^{* * *} \\
(.120) \\
\end{array}$ & & $\begin{array}{r}-0.392^{* * * *} \\
(.119) \\
\end{array}$ \\
\hline Pseudo $\mathrm{R}^{2}$ & 0.048 & 0.063 & 0.049 & 0.063 \\
\hline N. observations & 1234 & 1234 & 1234 & 1234 \\
\hline Test: $(a)+(b)=0$ & $2.71^{*}$ & $3.79^{*}$ & & \\
\hline Test: $(a)+(c)=0$ & & & $13.7^{* * *}$ & $12.1^{* * * *}$ \\
\hline Test: $(a)+(b)+(d)=0$ & & 0.45 & & \\
\hline Test: $(a)+(c)+(d)=0$ & & & & $3.88^{* *}$ \\
\hline
\end{tabular}


Table 6. Relationship between turnover and performance in family-controlled firms.

The dependent variable is modified top executive turnover: this is a dummy variable that takes value 1 in year $t$ if at least half of the top executives are replaced between $t$ and $t+1$ and leave all traded companies of the group to which the firm belongs. Size is the logarithm of total assets (in million Liras). Performance is the change in the ratio of EBIT and total assets between year t-1 and year t. There is a controlling shareholder-manager when at least half of the top executives belong to the family of the controlling shareholder. Controlling shareholder with high incentives is a dummy variable that takes value 1 when the controlling shareholder owns a fraction larger than 50 percent of the firm's cash flow rights. Robust standard errors (in parenthesis) control for correlation and clustering at firm level. Year dummies are included but the coefficients are not reported. Chi-squared tests are reported at the bottom of the table to test whether the interactive terms are significant. *, **, and *** denote significance at the 10,5 , and 1 percent level, respectively.

\begin{tabular}{|c|c|c|c|c|}
\hline & (1) & (2) & (3) & (4) \\
\hline \multirow[t]{2}{*}{ Number of top executives } & 0.098 & 0.058 & 0.097 & 0.054 \\
\hline & $(.067)$ & $(.085)$ & $(.077)$ & $(.085)$ \\
\hline \multirow[t]{2}{*}{ Size } & $-0.075^{*}$ & $-0.073^{*}$ & $-0.074^{*}$ & $-0.066^{*}$ \\
\hline & $(.041)$ & $(.040)$ & $(.044)$ & $(.043)$ \\
\hline \multirow[t]{2}{*}{ Performance (a) } & $-3.15^{* * *}$ & $-4.12^{* * *}$ & $-3.08^{* * *}$ & $-3.84^{* * *}$ \\
\hline & $(.923)$ & $(.831)$ & $(1.04)$ & $(1.06)$ \\
\hline \multirow{2}{*}{$\begin{array}{l}\text { Performance * Controlling } \\
\text { shareholder - manager }(b)\end{array}$} & & $3.83^{*}$ & & $3.97^{*}$ \\
\hline & & (2.14) & & $(2.13)$ \\
\hline \multirow{2}{*}{$\begin{array}{l}\text { Performance * Controlling } \\
\text { shareholder with high incentives (c) }\end{array}$} & & & -0.146 & -0.736 \\
\hline & & & $(1.57)$ & $(1.44)$ \\
\hline \multirow[t]{2}{*}{ Controlling shareholder - manager } & & $-0.521^{* * *}$ & & $-0.539^{* * *}$ \\
\hline & & $(.143)$ & & (.139) \\
\hline \multirow{2}{*}{$\begin{array}{l}\text { Controlling shareholder with high } \\
\text { incentives }\end{array}$} & & & 0.015 & 0.090 \\
\hline & & & $(.115)$ & $(.109)$ \\
\hline Pseudo $\mathrm{R}^{2}$ & 0.045 & 0.074 & 0.045 & 0.076 \\
\hline N. observations & 1234 & 1234 & 1234 & 1234 \\
\hline Test: $(a)+(b)=0$ & & 0.02 & & 0.00 \\
\hline Test: $(a)+(c)=0$ & & & $5.36^{* *}$ & $18.0^{* * * *}$ \\
\hline Test: $(a)+(b)+(c)=0$ & & & & 0.07 \\
\hline
\end{tabular}




\section{Table 7. Analysis of the firm's Q.}

OLS regression with fixed-effects by industry. The dependent variable is the firm's Q. Controlling shareholder manager is a dummy variable that identifies the cases where at least half of the top executives belong to the family of the controlling shareholder. Size is the logarithm of total assets (in million Liras). Robust standard errors (in parenthesis) control for correlation and heteroskedasticity. Year dummies are included but the coefficients are not reported. *,**, and $* * *$ denote significance at the 10,5 , and 1 percent level, respectively.

\begin{tabular}{|c|c|c|c|c|}
\hline & (1) & (2) & (3) & (4) \\
\hline \multirow[t]{2}{*}{ Controlling shareholder - manager } & $-0.041^{* *}$ & $-0.064^{* * *}$ & $-0.091^{* * *}$ & $-0.079^{* * *}$ \\
\hline & $(.018)$ & $(.020)$ & $(.023)$ & $(.022)$ \\
\hline \multirow[t]{2}{*}{ Voting syndicate } & & $0.262^{* * *}$ & $0.309^{* * * *}$ & $0.334^{* * * *}$ \\
\hline & & $(.053)$ & $(.056)$ & $(.057)$ \\
\hline \multirow{2}{*}{$\begin{array}{l}\text { Fraction of cash-flow rights owned by } \\
\text { the controlling shareholder }\end{array}$} & & & $0.002^{* * *}$ & $0.001^{* *}$ \\
\hline & & & $(0.000)$ & $(.000)$ \\
\hline \multirow[t]{2}{*}{ Size } & & & & $-0.060^{* * *}$ \\
\hline & & & & (.009) \\
\hline \multirow[t]{2}{*}{ Constant } & $0.981^{* * *}$ & $0.951^{* * * *}$ & $0.880^{* * *}$ & $1.72^{* * *}$ \\
\hline & $(.040)$ & $(.041)$ & $(.040)$ & $(.132)$ \\
\hline Adjusted $\mathrm{R}^{2}$ & 0.291 & 0.324 & 0.332 & 0.359 \\
\hline N. observations & 1234 & 1234 & 1234 & 1234 \\
\hline
\end{tabular}




\section{Table 8. Post-turnover performance.}

The table describes the performance in the years preceding and following a top executive turnover. The average (above), and the median (below) performance in the year before and after an event year are compared to zero and between themselves. The event is whether there is a turnover of at least half of the top executives in the year between $\mathrm{t}$ and $\mathrm{t}+1$. Ante-event performance is measured as the change in EBIT/Total Assets between $\mathrm{t}-1$ and $\mathrm{t}$. Post-event performance is measured as the change in EBIT/Total Assets between $t$ and $t+1$. Significance of means and medians is measured using a two-tailed t-test and a two-tailed Wilcoxon signed rank test, respectively. The tests of equality of Ante-event performance and Post-event performance are: a t-test with equal variance for the means and a Mann-Whitney test for the medians. ${ }^{*}, * *$, and $* * *$ denote significance at the 10,5 , and 1 percent level, respectively.

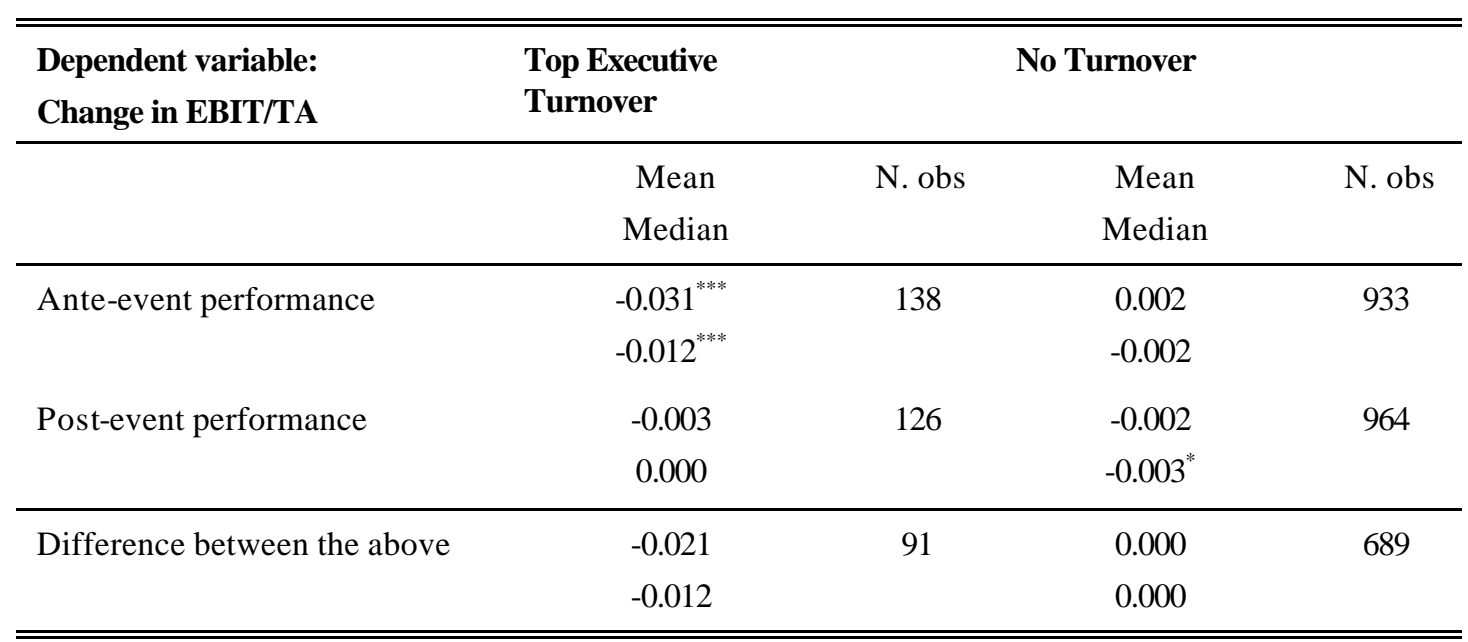


Table 9. Relationship between turnover and changes of control.

Panel A compares performance and turnover across three groups: the set of companies where the controlling stake is transferred (creditors excluded), those that are taken over by creditors and those that stay under the same controlling shareholder. Panel B tests the relationship between turnover and performance for each of the three groups separately. Both tables report averages (numbers above) and medians (number below). The tests of equality of the means are t-tests (with equal variance). Those of equality of the medians are Mann-Whitney tests. $*$, **, and $* * *$ denote significance at the 10, 5, and 1 percent level, respectively; 0 denotes no significant difference.

Panel A.

\begin{tabular}{lccc}
\hline \hline & N. obs & $\begin{array}{c}\text { Top Executive } \\
\text { Turnover }\end{array}$ & Past Performance \\
\hline Sale of the controlling stake (a) & 49 & 0.653 & -0.012 \\
Control shifts to creditors (b) & 27 & 1 & -0.007 \\
No change in control (c) & & 0.518 & -0.047 \\
& 1158 & 1 & -0.036 \\
\hline Test of difference between (a) and (c) & & 0.091 & 0.002 \\
Test of difference between (b) and (c) & 0 & $* * *$ & $* 003$ \\
\hline Test of difference between (a) and (b) & $* * *$ & $* *$ \\
& & $* * *$ & $* * *$ \\
\hline \hline
\end{tabular}

Panel B.

\begin{tabular}{lccc}
\hline \hline $\begin{array}{l}\text { Dependent variable is the change in } \\
\text { EBIT/ Total Assets between t-1 and } \mathbf{t}\end{array}$ & $\begin{array}{c}\text { Top Executive } \\
\text { Turnover (a) }\end{array}$ & No Turnover (b) & Test: (a)=(b) \\
\hline Sale of the controlling stake & -0.020 & 0.005 & 0 \\
& -0.008 & -0.007 & $*$ \\
Control shifts to creditors & -0.097 & 0.006 & $* *$ \\
No change in control & -0.058 & 0.005 & $* * *$ \\
& -0.012 & 0.004 & 0 \\
\hline \hline
\end{tabular}


Table 10. Structure of board of directors: role of non-executive directors and size of the board.

Probit regressions. The dependent variable (Top executive turnover) is a dummy variable that takes value 1 in year $\mathrm{t}$ if at least half of the top executives are replaced between $\mathrm{t}$ and $\mathrm{t}+1$. Size is the logarithm of total assets (in million Liras). Performance is the change in the ratio of EBIT and total assets between year t-1 and year t. An outside-dominated board is one in which more than 65 percent of directors are non-executives. A small board is a board with less than 6 directors. There is a controlling shareholder - manager when at least half of the top executives belong to the family of the controlling shareholder. Robust standard errors (in parenthesis) control for correlation and clustering at firm level. Year dummies are included but the coefficients are not reported. Chisquared tests are reported at the bottom of the table to test whether the interactive terms are significant. *, **, and $* * *$ denote significance at the 10,5 , and 1 percent level, respectively.

\begin{tabular}{|c|c|c|c|c|}
\hline & (1) & (2) & (3) & (4) \\
\hline Number of top executives & $\begin{array}{r}0.192^{* * * *} \\
(.071)\end{array}$ & $\begin{array}{r}0.167^{* *} \\
(.075)\end{array}$ & $\begin{array}{r}0.159^{* *} \\
(.069)\end{array}$ & $\begin{array}{l}0.131^{*} \\
(.071)\end{array}$ \\
\hline Size & $\begin{array}{r}-0.066^{*} \\
(.067)\end{array}$ & $\begin{array}{r}-0.064^{*} \\
(.035)\end{array}$ & $\begin{array}{r}-0.046 \\
(.038)\end{array}$ & $\begin{array}{r}-0.042 \\
(.037)\end{array}$ \\
\hline Performance (a) & $\begin{array}{r}-3.40^{* * * *} \\
(1.03)\end{array}$ & $\begin{array}{r}-3.79^{* * * *} \\
(.939)\end{array}$ & $\begin{array}{r}-4.01^{* * *} \\
(1.22)\end{array}$ & $\begin{array}{r}-4.30^{* * * *} \\
(1.25)\end{array}$ \\
\hline $\begin{array}{l}\text { Performance * Outside-dominated } \\
\text { board (b) }\end{array}$ & $\begin{array}{l}0.578 \\
(1.99)\end{array}$ & $\begin{array}{l}0.606 \\
(1.93)\end{array}$ & & \\
\hline Performance * Small board (c) & & & $\begin{array}{r}1.39 \\
(1.66)\end{array}$ & $\begin{array}{r}1.25 \\
(1.61)\end{array}$ \\
\hline $\begin{array}{l}\text { Performance * Controlling } \\
\text { shareholder manager }(d)\end{array}$ & & $\begin{array}{r}1.05 \\
(1.98)\end{array}$ & & $\begin{array}{r}1.08 \\
(2.00)\end{array}$ \\
\hline Outside-dominated board & $\begin{array}{l}0.094 \\
(.112)\end{array}$ & $\begin{array}{l}0.114 \\
(.112)\end{array}$ & & \\
\hline Small board & & & $\begin{array}{l}0.140 \\
(.112)\end{array}$ & $\begin{array}{l}0.138 \\
(.112)\end{array}$ \\
\hline Controlling shareholder - manager & & $\begin{array}{r}-0.408^{* * *} \\
(.116) \\
\end{array}$ & & $\begin{array}{r}-0.399^{* * *} \\
(.119) \\
\end{array}$ \\
\hline Pseudo $\mathrm{R}^{2}$ & 0.047 & 0.062 & 0.049 & 0.064 \\
\hline N. observations & 1234 & 1234 & 1234 & 1234 \\
\hline Test: $(a)+(b)=0$ & $2.83^{*}$ & $3.77^{*}$ & & \\
\hline Test: $(a)+(c)=0$ & & 1.93 & $5.1^{* *}$ & $8.87^{* * *}$ \\
\hline Test: $(a)+(b)+(d)=0$ & & 0.87 & & \\
\hline Test: $(\mathrm{a})+(\mathrm{c})+(\mathrm{d})=0$ & & & & 0.98 \\
\hline
\end{tabular}


Figure 1. Structure of the Pesenti group in 1995.

$\mathrm{P}=$ President, $\mathrm{CD}=\mathrm{CEO}$ (Consigliere Delegato), $\mathrm{VP}=$ Vice-President.

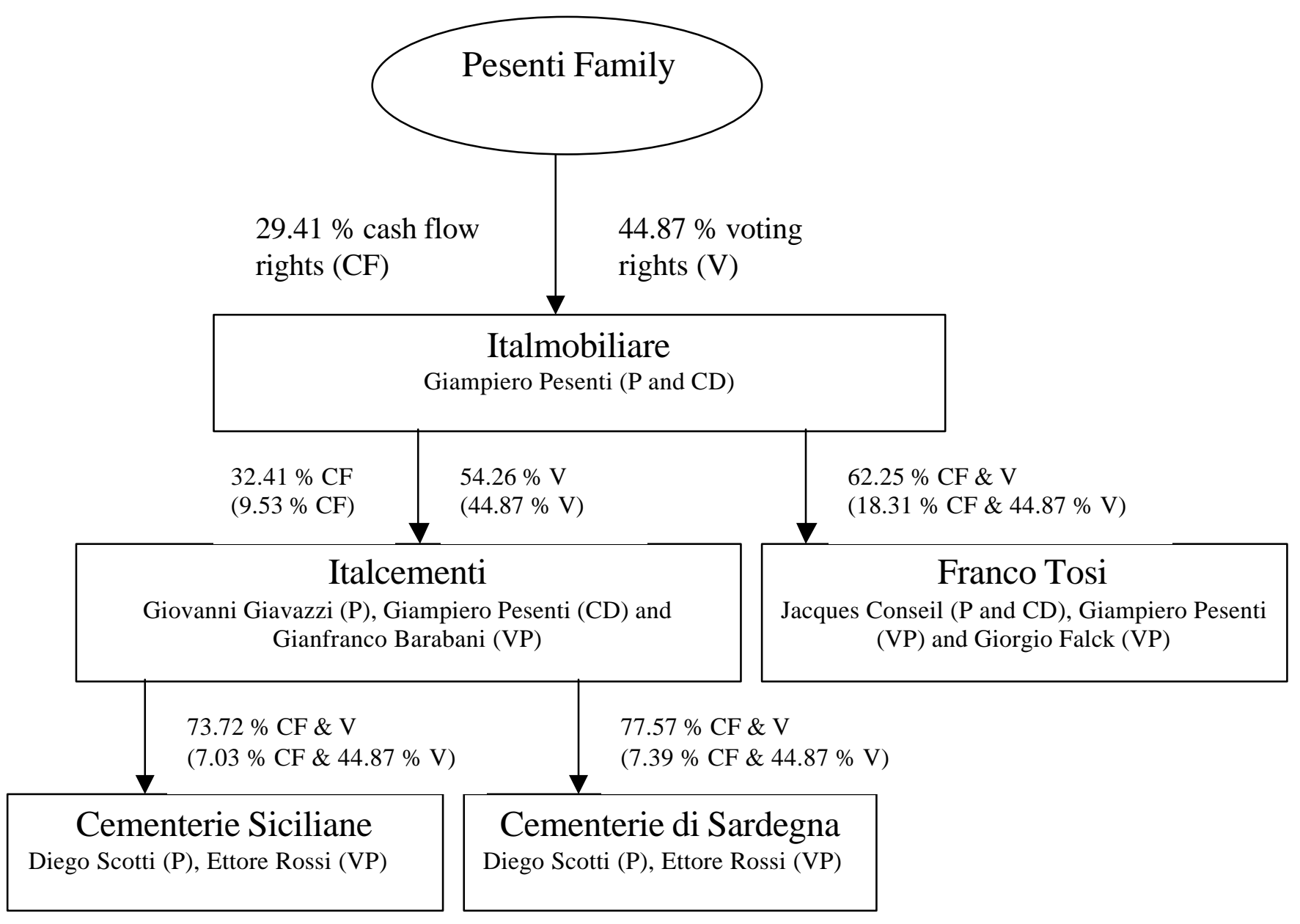




\section{Appendix:}

Table A1. Differences across family-, state-, foreign- and bank-controlled firms.

Probit regression. The dependent variable (Top executive turnover) is a dummy variable that takes value 1 in year $\mathrm{t}$ if at least half of the top executives are replaced between $\mathrm{t}$ and $\mathrm{t}+1$. Size is the logarithm of total assets (in million Liras). Performance is the change in the ratio of EBIT and total assets between year $\mathrm{t}-1$ and year t. Robust standard errors (in parenthesis) control for correlation and clustering at firm level. Year dummies are included but the coefficients are not reported. Chi-squared tests are reported at the bottom of the table to test whether turnover is related to performance in state-, foreign-, and bank-controlled firms. *, **, and *** denote significance at the 10,5 , and 1 percent level, respectively.

\begin{tabular}{lc}
\hline \hline & \\
\hline Number of top executives & $0.140^{* *}$ \\
Size & $(.064)$ \\
& -0.027 \\
Performance (a) & $(.028)$ \\
& $-3.04^{* * *}$ \\
Performance $*$ state ownership & $(.887)$ \\
dummy (b) & -0.753 \\
Performance $*$ foreign & $(2.21)$ \\
ownership dummy (c) & 2.35 \\
Performance $*$ bank ownership & $(1.93)$ \\
dummy (d) & $3.73^{*}$ \\
State ownership dummy & $(2.29)$ \\
& $0.451^{* * *}$ \\
Foreign ownership dummy & $(.124)$ \\
Bank ownership dummy & 0.134 \\
\hline Test: (a)+(b)=0 & $(.169)$ \\
& 0.031 \\
Test: $(\mathrm{a})+(\mathrm{c})=0$ & $(.164)$ \\
\hline
\end{tabular}

